\title{
A discussion of a geometric shape that became a symbol known as mandorla or vesica piscis, starting from a Pythagorean point of view
}

\author{
Amelia Carolina Sparavigna \\ Politecnico di Torino
}

Here we propose a discussion about the "mandorla" or "vesica piscis". It is a type of 2-dimensional lens, that is, a geometric shape formed by the intersection of two circles with the same radius, intersecting in such a way that the centre of each circle lies on the perimeter of the other. The aim of the discussion is that of understanding when such a geometric shape became a symbol and when this symbol received a specific name. We will find that the name "mandorla" was used long before the term "vesica piscis", which is the Latin translation of the German "fischblosen" (fishbladder) used by Albrecht Dürer in his book on geometry. Therefore, the name invented by Dürer was not used by the painter for a sacred form. However, after the middle of the nineteenth century the term "vesica piscis" exploded in literature. Its use was criticized and, at the same time, it was stressed that the proper term for the symbol is "mandorla". Nonetheless, the "vesica piscis" continues to be largely used in the sacred geometry, which ascribes symbolic and sacred meanings to certain geometric shapes and proportions. In the proposed discussion, we will also show that, recently, the 2-dimensional lenticular symbol has been related to the Pythagorean philosophy. It is told that the followers of this philosophy had the habit of using an apple for symbolic communications. Sliced across, the core of the apple is displaying a pentagram, but sliced lengthwise it forms two intersecting circles, that is a "mandorla". Then, the investigation about terms and related uses of this specific geometric shape is the core of the matter of our discussion or, let us tell, the "core of the apple", in a Pythagorean-like approach to find how a German "fischblosen" evolved into a sacred symbol, thanks to a translation into Latin.

Torino, 30 November 2020. DOI: 10.5281/zenodo.4298852 


\section{Introduction}

In Wikipedia ${ }^{1}$ we find that the "vesica piscis" is a type of 2-dimensional lens, a geometric shape formed by the intersection of two circles with the same radius, intersecting in such a way that the centre of each circle lies on the perimeter of the other. The Wikipedia item tells that the Latin "vesica piscis" literally means the "bladder of a fish" (swim bladder), because of its shape. In Italian, the shape's name is mandorla ("almond"). In visual arts, the mandorla is an almond-shaped aureola, a frame that surrounds the totality of an iconographic figure, such as Jesus Christ and the Virgin Mary. In Wikipedia, it is also told that the geometric figure appears in the first proposition of Euclid's Elements, where it forms the first step in constructing an equilateral triangle using a compass and straight-edge. The triangle has as its vertices the two circle centres and one of the two sharp corners of the vesica piscis.

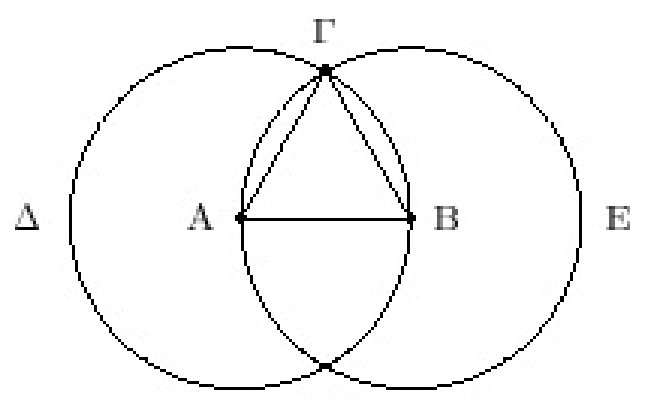

The equilateral triangle inside the intersection

The geometry of the figure is interesting for its related properties. For instance, we can have from it the geometric representation of the square roots as shown in [1]. It is also the geometric shape used in architecture, by Gian Lorenzo Bernini too in the "ovato tondo" of St. Peter's Square in Rome [2]. However, besides being important for its geometric properties, this shape became a symbol, during its long life starting from the first decorations of ancient artefacts $[3,4]$. When did the symbolic meaning arose and how was its name chosen, these are the questions we would like to solve. Therefore, let us call it as "vesica piscis" for the sake of simplicity, but please remember that it is a recent name given to the geometric shape.

1 https://en.wikipedia.org/wiki/Vesica_piscis archived https://archive.is/RmWB9 


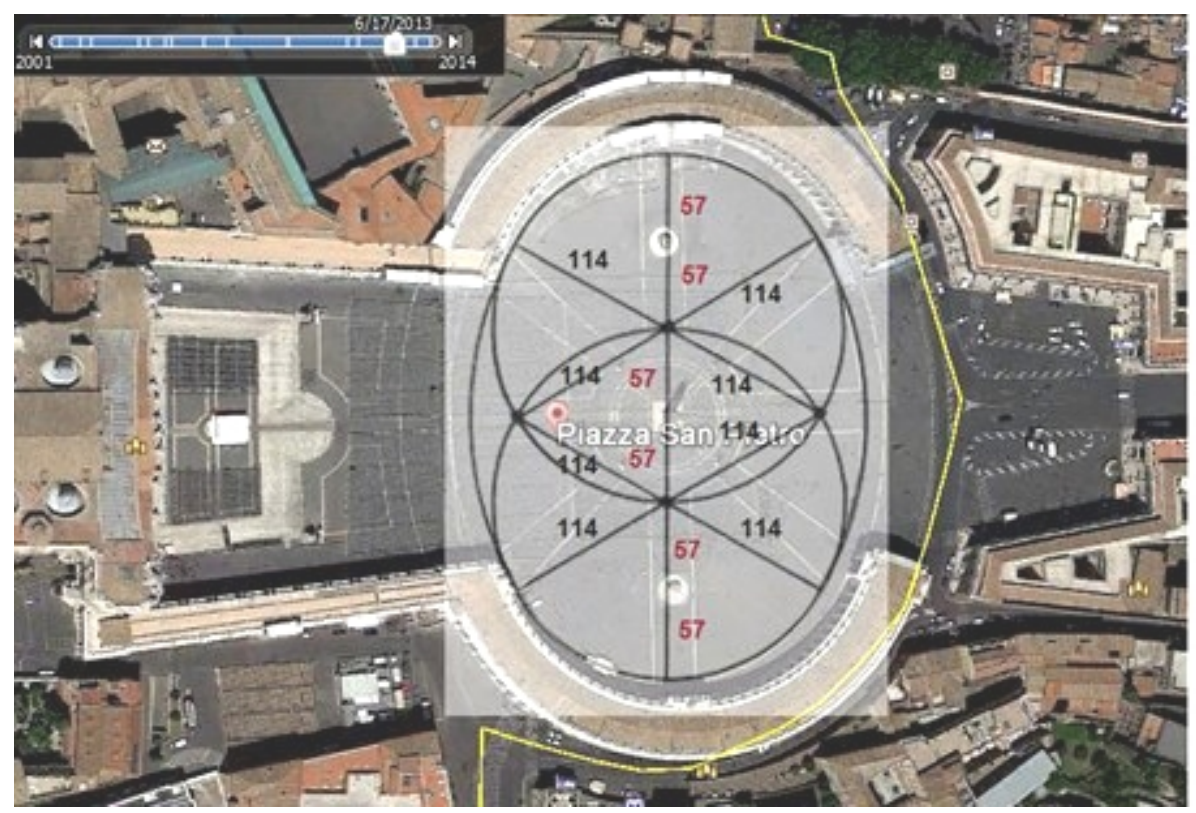

Bernini's "ovato tondo" in Saint Peter's Square, surrounded by the colonnades. The obelisk acts as a pivot. Note that obelisk and fountains are halving the bases of equilateral triangles. To evidence the geometry of this ovato, black and red numbers are the lengths (in pixels) of the corresponding lines [2].

The satellite image is a Google Earth courtesy.

\section{Was it a Pythagorean symbol? How did it migrate into Christianity?}

It seems that the 2-dimensional lenticular shape was a symbol of Pythagorean people [5]. In the "Pythagoras and the Mystery of Numbers", written by Kate Hobgood it is told the following. "Of all shapes, the circle is the parent of all following shapes. When a circle is mirrored, two mirrors are created. These two circles side by side build a foundation for all numbers. The overlap of the circles allows each one to share the center of the other. ... From this shape, a triangle, square, and pentagon can be produced. And the relationship between these figures justifies the existences of further number principles". To have the vesica piscis, it is necessary to start from the circle. 
The figure of the circle "is the most stable, and the mathematical philosophers also called it The First, The Essence, The Foundation, and Unity. Pythagoras believed the monad to be god and the good. The monad is origin of the One. The monad is the seed of a tree", and from this seed the branches of the tree are generated, representing all the numbers. "The monad in relation to other numbers preserves the identity of every other number or anything it encounters. Any number multiplied by one is itself, and any number divided by one is itself". After the circle, that is the Monad, we have the vesica piscis, which is the Dyad, and from it we have all the other figures.

The discussion proposed by Kate Hobgood is suggesting just a further reading, which is the Divine Proportion: $\Phi$ (Phi) In Art, Nature, and Science, by P. Hemenway, (2005), Sterling Publishing Co. . Then, we do not know who are the mathematical philosophers mentioned above.

\section{Mystery and Enigma}

Now, about the vesica piscis and the Pythagoreans, we read something in [6]. Graham Hancock tells that "The Pythagorean secret sign, the cutting of the apple, was the transmission of a shared wisdom, that of the knowledge of the numerical harmonies of nature revealed through the phi ratio of the pentagram, and, by extension; the vesica piscis. This message was non verbal. All you needed to grasp it was the knowledge of mathematics, the universal language".

It seems that Hancock is referring to the manner of creating a pentagon from the vesica piscis as proposed by Albrecht Dürer.

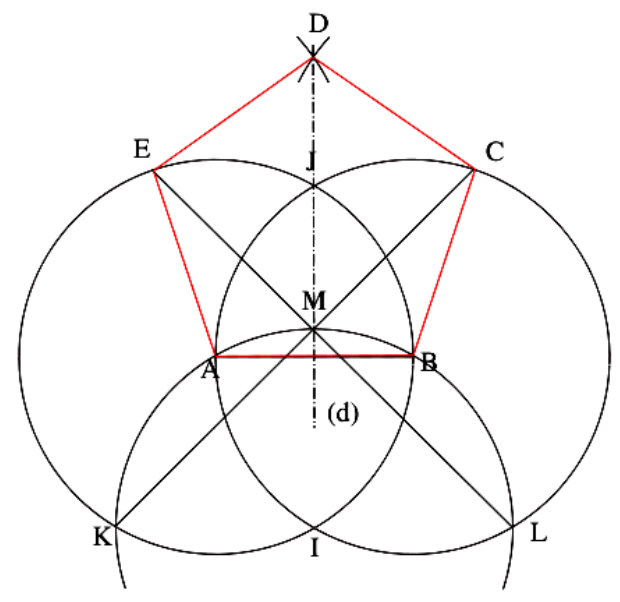

Pentagone construit à la règle et au compas. Méthode de Dürer. Pentagone equilatéral mais non equiangle. Approximation d'un pentagone régulier Regular pentagon. Ruler-and-compass construction. Dürer's method. Not exactly a regular pentagon (Courtesy: HB for Wikipedia) 
However, we can have a regular pentagon starting from vesica piscis as shown in [7].

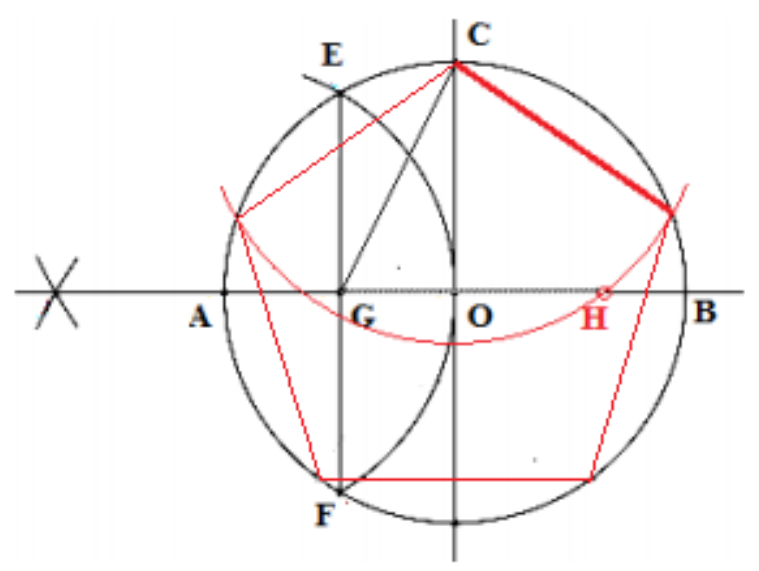

See details in Ref. 7.

In [8], it is told by Emerson DeAnna that the "triple interwoven triangle or pentagram, the star-shaped regular Venus pentagon associated with the Goddess religion, was used as a symbol of recognition by the Pythagoreans, and their closely guarded secret sign was the apple or pomegranate, cut laterally across the core to reveal the seed pod in the shape of the pentagon". Actually, cutting laterally an apple is an uncommon manner to slice it. A "snipped view" of Google Books tells that in Africa Through the Mists of Time, by Brenda Sullivan [9], we can find it too, such as in page 122 of Architecture and the Urban Environment by Derek Thomas [10].

Currently, I am unable to give you any ancient source on Pythagoreans and apples.

\section{From Pythagoreans to Christianity}

We can find also about the Pythagorean philosophy in the article [11], written by Rostislava Todorova, and in references given therein. Ref. 11 is an article concerning the migration of the symbol from Pythagoreans to Christianity. And there we can find a remarkable discussion distinguishing mandorla and vesica piscis.

"The "Christian mandorla" is a symbol with multilayered meaning and this diversity is caused by the difficulties in explanation of the essence of what the Glory of God really is. The initial position of the present investigation is that the roots of mandorla as a visual sign can be seen in the Pythagorean idea of vesica piscis" [11]. Therefore, the origin of a symbolic meaning of the geometric shape was in ancient philosophy. "It can be assumed that this geometrical vertically-pointed oval form was adopted by 
Christian art as a visual symbol of the Divine Glory of God." [11] This symbol was therefore adopted because of its philosophical background, "in the same manner the adoptions of many other notions from pagan Platonism and Neo-Platonism for example, were made by Christianity".

In the article [11], it is also told that "Firstly, in the mystery religions and famously

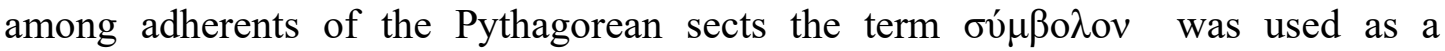
designating sign and as a guarantee for authentic appurtenance. Special symbols had been used as a secret passwords or enigmatic verbal or visual formulas that verify the membership in a particular cult. (Struck $2005^{2}$ ) One of these symbols was the apple Pythagoreans had the custom to bring an apple as a gift to the strangers and those who understood its symbolism would slice the apple. Sliced across, the apple core depicts a pentagram in the center of a circle, yet sliced lengthwise forms two intersected circle sin the middle of which a vesica piscis appears".

Actually Peter Struck discussed the Pythagorean symbols in general and he is not talking about the apple. It seems therefore that what is written by Rostislava Todorova has a source different from Struck (may be those given above, where we have seen the cutting of the apple to have pentagons or pentagrams). The apple "sliced lengthwise forms two intersected circles in the middle of which a vesica piscis appears" is an observation made by Todorova.
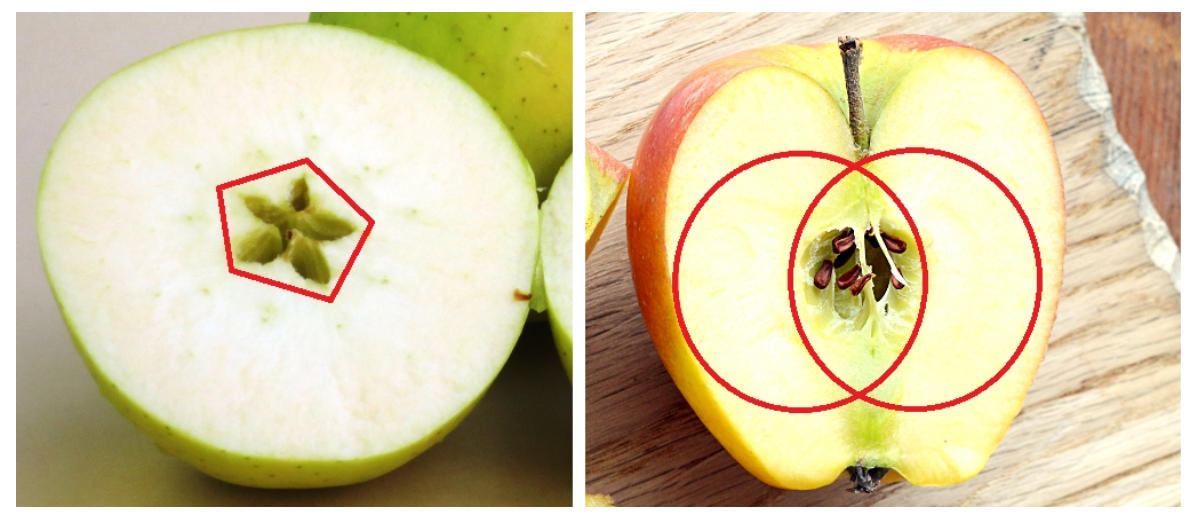

The core of the apple cut to have a pentagram or to see a mandorla (endocarp) inside.

2 In [11], we find the following reference: Struck, Peter T. 2005. Symbol and Symbolism. In the Encyclopedia of Religion. 2nd ed. 13th vol. Detroit: Macmillan Reference USA. Here a link https://www.encyclopedia.com/environment/encyclopedias-almanacs-transcripts-andmaps/symbol-and-symbolism 
In [11], it is also told on the vesica piscis that is "has been generally believed that the vertical vesica piscis denotes fertility and divine femininity, and the horizontal one symbolizes the unity of being (De Vries, 19743)". The Pythagoreans used it as a perfect sign of harmony of the being which is possessing inherent opposites. After all, according to [11], it became the symbol of a unity between material and sacred space. "This esoteric symbol" rapidly became very popular, so as to being used to represent the Cosmos and the birth of life, the feminine archetype of being, and so on (see [11] and references therein). From the Christian point of view, the "vesica piscis" represents together terrestrial and celestial, human and divine, bound together after the Christ Resurrection [11]. And therefore we find the use of the "mandorla", as previously told, in the Christian iconography.

As told by Rostislava Todorova in [12], the "mandorla enters in the Christian imagery as a visual representation of the Glory of God, although some scholars have their reasons for considering it as a symbol with much more feminine meaning [the author is mentioning Ref.13]". So we have that the term "mandorla" is more suitable to represent a feminine symbology.

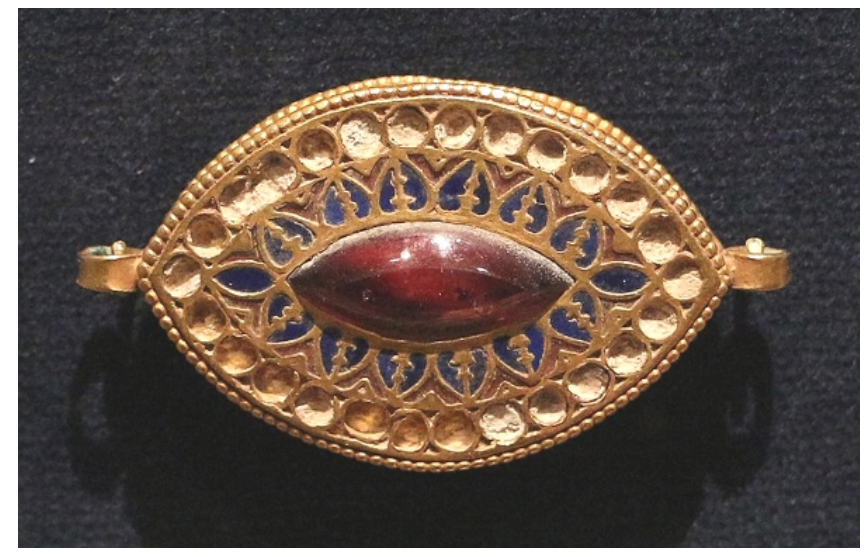

Impero romano d'oriente, pendente a mandorla, in oro, lapislazuli, granati e vetro, $V$-VI secolo

Byzantine metalwork in the Cleveland Museum of Art. Image Courtesy Sailko for Wikimedia.

3 De Vries, Add. 1974. Dictionary of Symbols and Imagery. London: North-Holland Publishing Company - Amsterdam. 


\section{The mandorla}

Here what Wikipedia is telling about mandorla": "It is commonly used to frame the figure of Christ in Majesty in early medieval and Romanesque art, as well as Byzantine art of the same periods. It is the shape generally used for mediaeval ecclesiastical seals, secular seals generally being round. Mandorla is Italian for the almond nut, to which shape it refers. It may be elliptical or depicted as a vesica, a lens shape as the intersection of two circles. Rhombic mandorlas are also sometimes depicted. - In icons of the Eastern Orthodox Church, the mandorla is used to depict sacred moments that transcend time and space, such as the Resurrection and the Transfiguration of Jesus Christ and the Dormition of the Theotokos. These mandorla often are painted in several concentric bands of different color, which become darker in progression to the center of the mandorla".

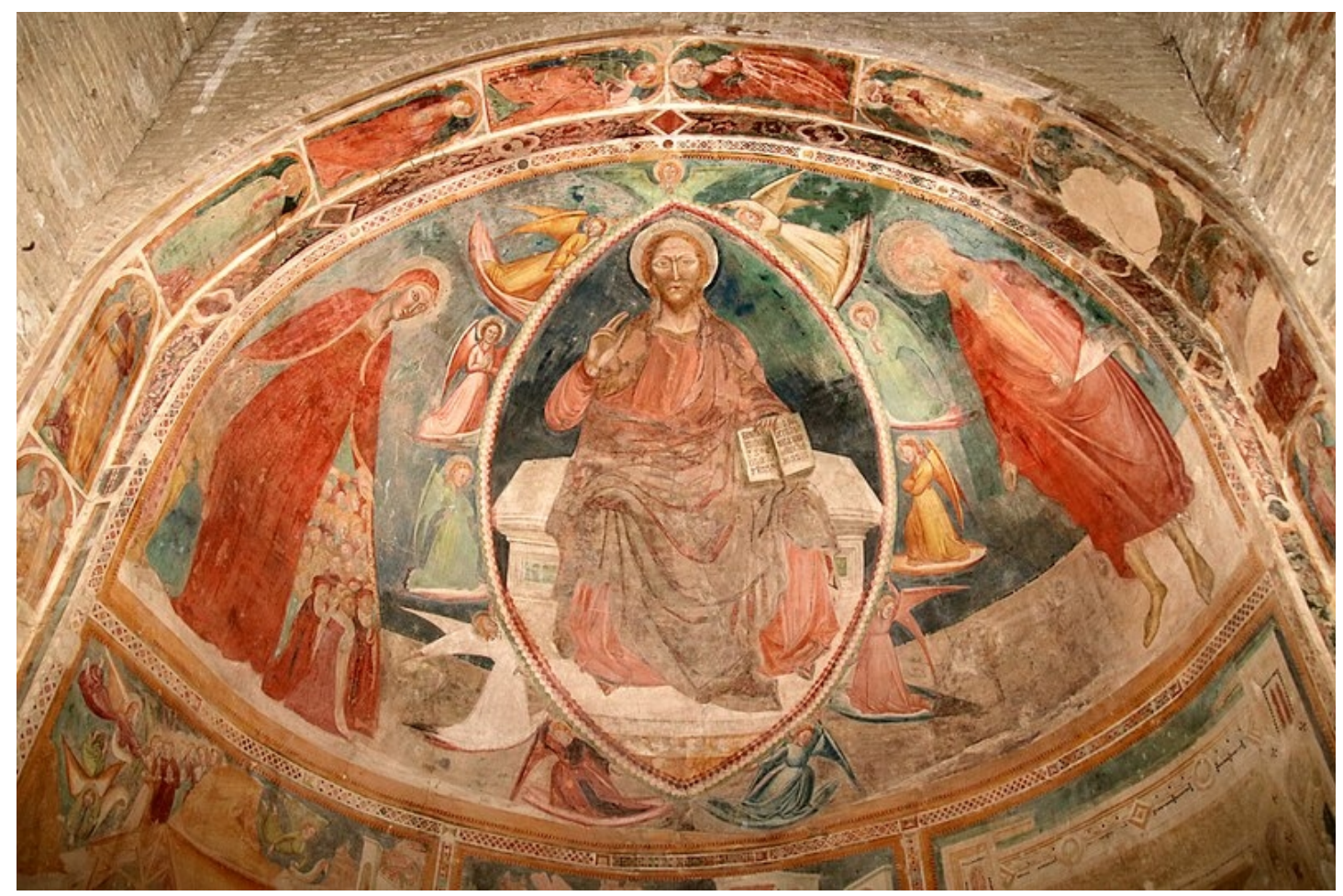

Maestro di Offida, Cristo in mandorla tra S. Giovanni Battista e la Madonna della Misericordia, seconda metà sec. XIV. Basilica della Santissima Annunziata (Montecosaro). (Image courtesy by Mongolo1984 for Wikipedia)

4 https://en.wikipedia.org/wiki/Mandorla archived https://archive.is/sJ4i5 


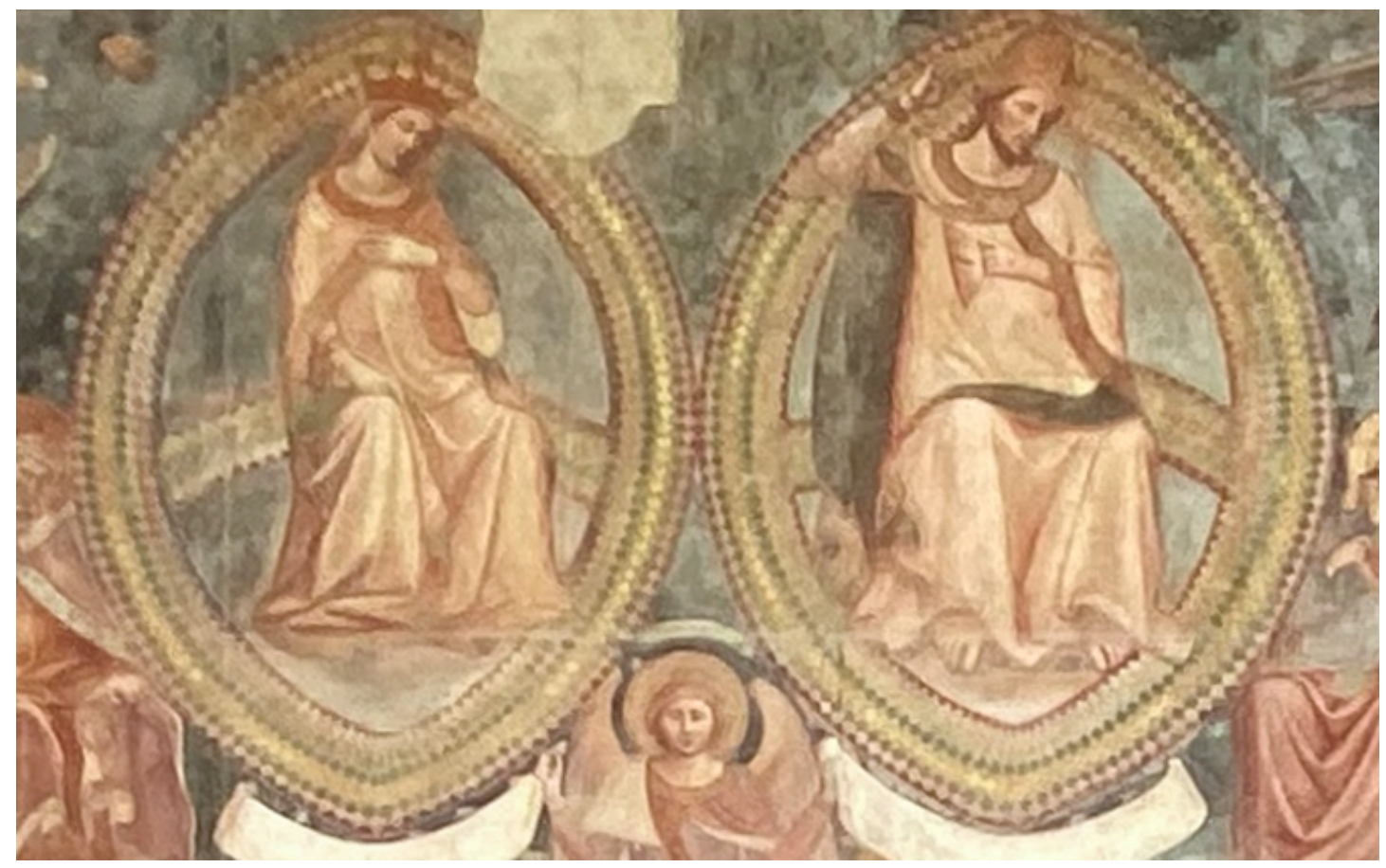

Dettaglio del "Giudizio finale e Inferno" dipinto tra il 1336 e il 1341 da Buonamico Buffalmacco ed ubicato nel Campo Santo monumentale di Pisa. (Immagine cortesia di Federigo Federighi per Wikipedia)

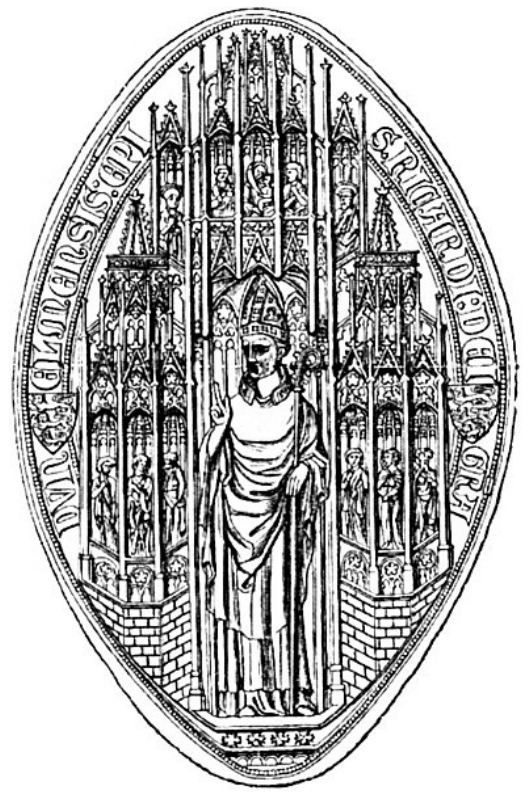

Seal of Richard de Bury (Richard Aungerville), Bishop of Durham. Mandorla-shaped seal The Latin inscription is: S(igillum) Ricardi dei grat(ia) Dunelmensis epi(scopus) ("seal of Richard, by the grace of God Bishop of Durham"). Arms of King Edward III on either side. Image courtesy Wikipedia. 


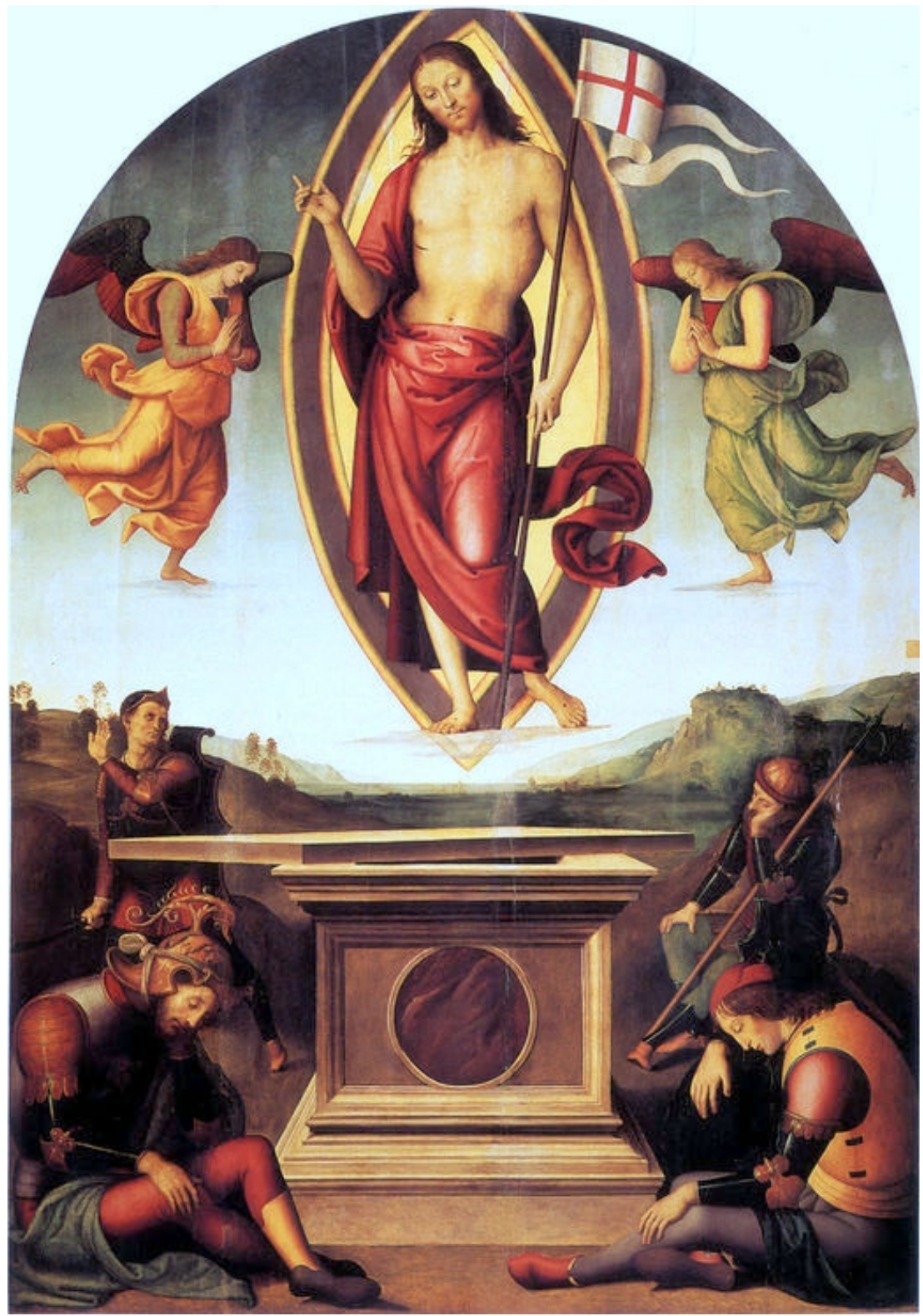

La Resurrezione di San Francesco al Prato del Perugino, databile al 1499 circa e conservato nella Pinacoteca Vaticana. . Note please the mandorla surrounding Jesus Christ. 


\section{Use "mandorla" instead of "vesica piscis"}

Let us continue reading [11], where we find reasons to use "mandorla" instead of "vesica piscis".

"The term vesica piscis has been completely rejected from the most scholars because of at least two reasons. Firstly, the accent of meaning of the old pagan symbol as a sign of the unity was chanced into a token of the Divinity of Christ. Thus, the Christian mandorla can be connected more closely with the way of expression of the divinity of ancient gods and the halo as a visual sign of it". The depiction of a "nimbus", that is of a luminous form around the head of gods or holy persons is present in many ancient religions, and "partakes of the full range of light symbolism from both Western and Eastern traditions. ... Secondly, change of the term can be seen as a direct attempt for fading the feminine and vaginal meanings of the symbol [14], because of their unsuitability with the Christian dogmatics and the Christian way of understanding God and the Holy Trinity. Precisely - tells Rostislava Todorova in [11] - this was the reason [that] forced Didron to write his sentence about the term vesica piscis: a term so gross deserves to be expunged from every refined system of terminology...invented and employed even to abuse..."[15]. And also: "Didron actually gave voice to a thought presumably shared by others since little was written by reputable art historians about this widely used shape in the Christian iconography. Most likely this was the real reason the term "mandorla" to has come in use - to describe in more "Christian" religious terms this visual device as a window into sacred space or as an aureole of the Glory that surrounds figure of Christ, the Virgin Mary and rarely some saints [14]" [see [11] and references therein].

Then, let us try to understand when the term "vesica piscis" was created.

\section{Who was the first to use the term "vesica piscis"?}

We can find the answer in "A Concise Glossary of Terms Used in Grecian, Roman, Italian, and Gothic Architecture", by John Henry Parker (1846).

"VESICA PISCIS: a name applied by Albert Dürer to a pointed oval figure, formed by two equal circles, cutting each other in their centres, which is a very common form given to the aureole, or glory, by which the representations of each of the three Persons of the Holy Trinity and the Blessed Virgin are surrounded in the paintings or sculptures of the middle ages. It has been conjectured that it was adopted from the idea that this figure is symbolical, and significant of the Greek word IX $\Theta Y \Sigma$ (a fish), which contains the initial letters of the name and titles of the Saviour; this form, however, is by no means always given to the aureole, and the idea of any peculiar symbolical meaning being attached to it appears to have been adopted almost exclusively by English antiquaries. This form is sometimes found in panels and other architectural features, and is extremely common in medieval seals, especially those of 
bishops and monastic establishments".

Dürer wrote his book on geometry in German, and the term he used is "fischblosen" [16]. We can find it is a Google Book, entitled Opera Alberti Dureri: das ist alle Bücher des weitberhümbten und künstreichen Mathematici und Mahlers Albrechten Durers von Nürenberg so viel deren von ihm selbst in An. 1525 u. 1528 kurtz vor u. gleich nach seinem todt in Truck geben; jetzo denselben zum besten aus mangel d. Exemplarien mit sein selbst eigenen gemachten u. geschnittenen zugehörigen Fig. von newem auffgelegt und getruckt- Albrecht Dürer. Jan 1604. Jansen. Here in the following the image from the book, where Dürer is using and mentioning three fish bladders. Let us stress that it is a book on geometry.

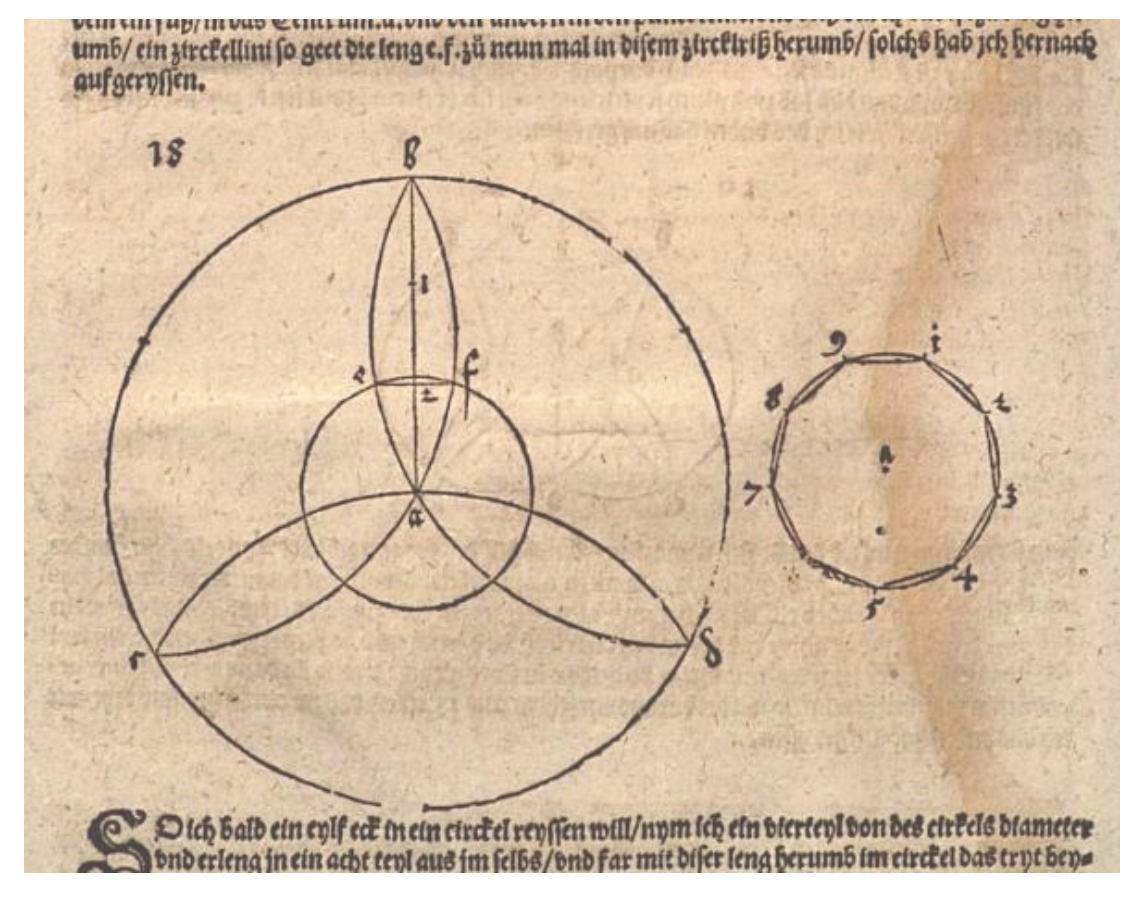

Let us stress that "vesica piscis" is the Latin translation of the German "fischblosen" (fish-bladder), a term used by Albrecht Dürer in his book on geometry. Therefore, the name invented by Dürer was not used by the painter for a sacred form to represent Jesus Christ. Once more: it was used for geometry. It is also necessary to note that, in the geometric shape depicted by Dürer, there is not the "vesica piscis" mentioned by Wikipedia, because his "fischblosen" is obtained by two circles for sure, but not "in such a way that the centre of each circle lies on the perimeter of the other". 
The curvilinear angle

From Wikipedia: "The angle between a line and a curve (mixed angle) or between two intersecting curves (curvilinear angle) is defined to be the angle between the tangents at the point of intersection. Various names (now rarely, if ever, used) have been given to particular cases ... ${ }^{\prime 5}$. Then, the two angles of the vesica piscis are curvilinear angles.

We find curvilinear angles shown in the Opere di Orontio Fineo del Delfinato diuise in cinque parti; Aritmetica, Geometria, Cosmografia, \& Oriuoli, tradotte da Cosimo Bartoli ... et gli Specchi, tradotti dal caualier Ercole Bottrigaro, .. (Oronce Finé, 1494 - 1555). After these angles, the author is also showing the spherical coordinates.

6 L'Angolo curuilineo, ciod di linee curue, fi fa ò nell a medc fima fu perficie piana, ò nella curwa. Sono angola curuilinei nella fuperficie piana quegli cbe fon caufati dallo fambiewole toccamento di duoi cerchi nel medefsmo piano, $\dot{\sigma}$ nö in cerchi pofti in diuerfi piani,ouero dal lo interfegamento loro. Si come fono gli angoli $B C D, C D G$, ouero $C G F, d$ de fimili a questi, comprefi dalle fcambieuoli interfegationi de $i$ cercbi $\triangle B C$,

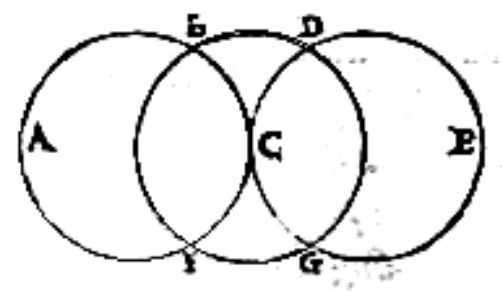
$C D E, \& B D F, n e^{\circ}$ punti $B D, \& F G$, ò daltoccamento $C$.

Ma nella fuperficie curua, fi cawfano propriamente gi angoli curuilinei, mediante le feambiewoli interfecationi de $i$ cerchi della $f w$ perficie terminatiua di fuora, fopra on corpo sferico, (dol quale) trattaremo dipoi) perilcbe comunemente fi cbiamano angoli sferali. Iquali in quel modo cbe fipud, pare cbe fiano rapprefentati da gli

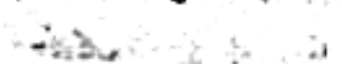

In this work on geometry, we do not find mentioned a "vesica piscis". The figure above, where we can easily see this specific lens, has no specific name.

5 en.wikipedia.org/wiki/Angle - The list of the names of curvilinear angles is from Chisholm, Hugh, ed. (1911), "Angle", Encyclopædia Britannica, 2 (11th ed.), Cambridge University Press, p. 14 


\section{Is the fish a symbolical representation of Christ?}

Let us read now what we can find in "History of the Foundations in Manchester of Chirst's College, Chetham's Hospital, and the Free Grammar School", Volume 2, by Samuel Hibbert, edited by T. Agnew and J. Zanetti, 1834. And also in "The Episcopal See of Manchester: Continuation of the history of the collegiate church: an architectural description of the Collegiate church and College of Manchester", by Samuel Hibbert, 1848.

"The fish is a symbolical representation of Christ, which is called by Albert Dürer, Vesica piscis, ${ }^{6}$ the bladder of fish. It is, however, the fish itself which appears among the sculptural ornaments of ancient cathedrals and other churches, together with its accompanying inscription IX $\Theta Y \Sigma$ piscis. The word is formed after the custom of the cabalists; and there is the following brief account of it in the Nouvelle Diplomatique. Above and on the left side of an inscription upon a piece of painted glass, published by the Senator Buonarotti ${ }^{7}$, is seen the Greek word IX $\Theta Y \Sigma$, a fish. It is composed of five letters, which, taken separately, form [the Greek phrase having the following meaning] Jesus Christ, Son of God, the Saviour. The word IX $\Theta Y \Sigma$ is a symbol which the early Christians engraved upon their seals, rings, lamps, tombs, and sepulchral urns, together with the figure of a fish. This custom was in allusion to the waters of baptism, in which the faithful are regenerated; as a fish is produced in water, and cannot live out of that element. In this sense, Tertullian calls Christians Little Fishes, Nos pisculi secundem IX $\Theta Y \Sigma$ nostrum J. Christum in quo nascimur [a note in the text tells that the Tertullian passage is not properly reported]. ... There are other explications of this acrostic, which Eusebius and St Augustine ascribe to the Erytraean Sibyl, which is by no means probable. Perhaps, after all, the word, invented after the example of the Jewish Cabalists, was first employed by the Christians, during the ages of persecution, as a secret token of recognition, like the modern freemasons, and the gnostics, who employed certain signs known to themselves alone".

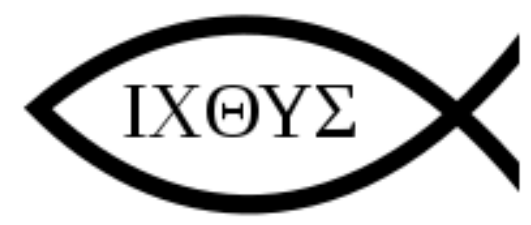

6 Here a note that we can find in the book. "Dureri Inst. Geometric. Lib. ii. p. 56. - In the Archaiologia, Vol. XIX. Art. xxxvii. is a luminous paper by Mr Kerrich, in which he ingeniously endeavours to show, that the Vesica Piscis had a great influence on the Christians of the middle ages, in the proportions of their religious edifices, ans illustrates his history by very ingenious and curious diagrams".

7 https://it.wikipedia.org/wiki/Filippo_Buonarroti_(antiquario) 
Besides the note of the Editor, telling that Tertullian was not properly quoted, let us also add an observation. The phrase "The fish is a symbolical representation of Christ, which is called by Albert Dürer, Vesica piscis, the bladder of fish" is wrong. As we have seen, we find the "fischblosen" in a book on geometry. Dürer is not mentioning Christ, and therefore, for Dürer, it was a geometric shape and not a symbol of Jesus Christ. Moreover, the figure given above, with IX $\Theta Y \Sigma$ inside a geometric shape cannot be associated to the vesica piscis, because it is depicting a fish.

The "fischblosen" became the name of a symbol because it was translated into the Latin "vesica piscis", and the term was used by Thomas Kerrich to describe the sharp-pointed figures in architecture, instead of the term "mandorla".

\section{Kerrich and the vesica piscis}

Thomas Kerrich ${ }^{8}$ (1748 - 1828) was an antiquarian, fellow of Magdalene College, Cambridge, and Principal Librarian to the University of Cambridge.

We find information on him in "Illustrations of the Literary History of the Eighteenth Century by John Nichols, 1831". "In 1815 Mr. Kerrich exhibited to the Society of Antiquaries, an urn discovered by some workmen ... In 1820 he communicated some "Observations on the Use of the mysterious figure called Vesica Piscis, in the Architecture of the Middle Ages and in Gothic Architecture". This is accompanied by fifteen plates, containing no less than 65 draughts of the ground - plans and arches of ancient ecclesiastical edifices, both abroad and at home".

And we can find also a letter. In this letter we read that Kerrich wrote that the geometric figure of the lens, that we know as mandorla or vesica piscis, had no name. In fact, as we will see in the following discussion, it had the name of mandorla.

Burnham, May 6, 1820. "DEAR BALME, You have pleasure in reading letters, so here is another; and I will try to make it such a one as you wish to have from me. My great object in all that I have ever done, or thought, or written about Norman and Gothic Architecture, was to recover, if possible, the rules and principles of the science of art (which ever you may choose to call it), which are lost; and this I should not despair of seeing effected if men would seriously examine and study the buildings, in those styles that are left, so as to understand them, and not waste their time in frivolous disputes as to what they should be called, or fruitless inquiries from whence Gothic Architecture was brought, and hopeless guesses concerning the origin of the Pointed Arch. All these I have endeavoured to discourage as much as I could in the former dissertation I sent to the Society, which was meant as a mere introduction to that now before them, which is the result of many years study, and a patient examination of a great number of buildings. I in that made some remarks upon the

8 https://www.nationalgallery.org.uk/artists/thomas-kerrich 
particular nature of Gothic Architecture, the simplicity of its leading forms, the astonishing variety of which it is capable, which exceeds infinitely every thing that could possibly be done in the Antique, or, as it is called, regular Architecture. I hinted the use which had been made of a mysterious figure (for which we had no name) by the old architects in making their designs, long before the Pointed Arch was in vogue. I observed its having been used for the form of ecclesiastical seals, and other things designed for sacred purposes; and said, that on accidentally looking into Albert Dürer's book of Geometry, I had found that he named it Vesica Piscis. He must therefore answer for that name; I only adopted it as better than Gothic Oval or Gothic Ellipsis, which is absolutely intolerable, but I have heard it called by both these names; and I believe I went so far as to assert, that the influence of this figure was very extensive. This I meant to show, so far as architecture is concerned, in the present paper, which I then meditated, and have now sent . ... Now you may do exactly as you please with all this; you may communicate the whole, or as much of it as you think proper, to our brother Antiquaries. Yours sincerely, T. KERRICH . " The paper is published in [17].

Here the abstract. "In my observations on Gothic Architecture, published in the Sixteenth Volume of the Archaeologia, I ventured to express my belief that the rules and principles of it might be recovered by a patient examination of the numerous buildings in that style still remaining. And I also remarked, that the Mysterious Figure, which seems to have been called Vesica Piscis, had a great influence upon the forms of all sorts of things, which were intended for sacred uses; after the establishment of Christianity".

It seems that Kerrich was the first to use the term vesica piscis, after translating it from German to Latin. Let us stress once more that the Dürer's book of Geometry is written in German, and that, therefore, vesica piscis is Kerrich's translation. After the publication of Kerrich's work, the vesica piscis became a term used by English antiquaries. However, in "The Ecclesiologist, Volume 7", Cambridge Camden Society, 1850, in a discussion of "The History of Stained Glass, from the earliest period of the art to the present time", by William Warrington, 1848, it is told the following.

"3. Closely connected with this inadequate perception of the principles of ancient, or indeed any, art, is the ignorant use of the sacred form, unhappily called the Vesica Piscis. This is nothing but an elongated aureola: i.e. "a glory," as it used to be called, closing round and adapted to the shape of the body: and which most fittingly might be restricted to the Glorified and Sacred Form of our Lord in His Humanity. It represents the light issuing from Him Who is the Light. To use it as a mere pretty figure which it is not - is not only simply irreverent, but absurd. This is Mr. Warrington's treatment of it. To place the group two figures, \& c ., in the Baptism, in a Vesica at Trinity church, Brompton, is silly enough; but in the design for Ely, not only is S. 
Etheldreda thus aureolized, but an ingenious design of two vesicæ interlaced within a single one, gives Mr. Warrington the opportunity of placing twenty-two coats of arms, and six devices, much resembling bottle brushes, each within this most sacred outline. So utterly has Mr. Warrington missed the idea of this conventional form, that while at Brompton he uses it seven times, and never once for what alone it is applicable - for a single figure - in six of these instances it actually encloses a circle, and the circle encloses something else, and this something else is a whole group of several figures".

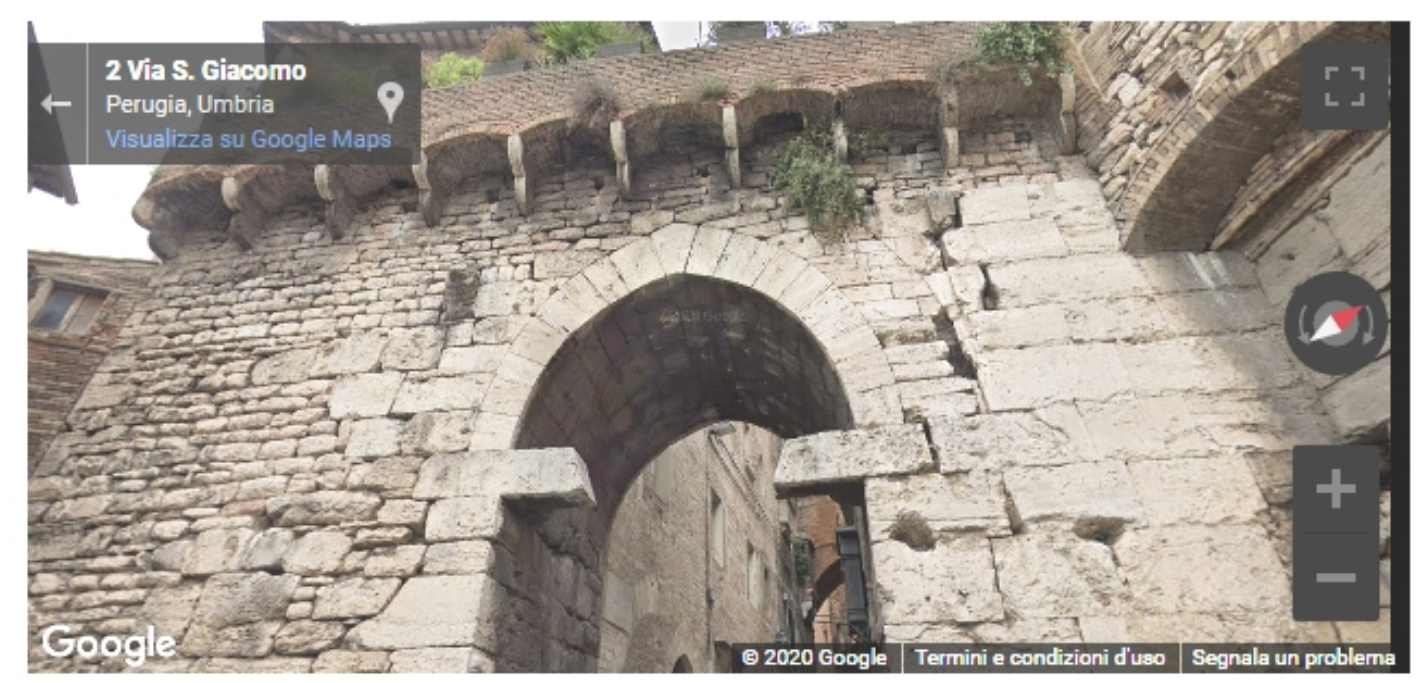

The Porta Eburnea, that is Ivory Gate, in Perugia, between via Bruschi and via San Giacomo, also known as "Arco della Mandorla", Almond Arch.

$$
\text { (Image courtesy Google Maps) }
$$

http://turismo.comune.perugia.it/poi/porta-eburnea-ivory-gate.

This gate belongs to the Etruscan City Walls and maintains the original quoins in travertine up to the transom of the arch, replaced during the Middle Ages with a pointed arch, whence the name "Arco della Mandorla" (Almond Arch). The ancient name "Eburnea" (made of ivory) is referred to the elephant ivory tusks, symbol of the District. 


\section{How to draw arches according to Villard de Honnecourt}

Villard de Honnecourt was a 13th-century master of masonry from Picardy, France. $\mathrm{He}$ is known only because of his surviving portfolio or "sketchbook", containing drawings and designs of a wide variety of subjects. Villard includes some technical procedures, the drawings of mechanical devices, and the suggestions for making human and animal figures, and notes on the buildings and monuments he had seen. And in Gallica, https://gallica.bnf.fr/ark:/12148/btv1b10509412z, we can find the notebook (original) and a Facsimile illustrated by commentaries and descriptions, made by by Lassus, JB, Darcel, A, Quicherat, JÉ, and Willis, R (1859) at the following link: https://archive.org/details/facsimileofsketc00vill/ page/4/mode/2up

In his notebook we find how to draw three kind of arches with one opening of the compasses, as explained by the facsimile.

"Par chu fait om trois manires dars. a compas ovrir one fois."

"Par ce moyen l'on fait trois manières d'arcs avec une seule ouverture de compas."

"Thus can be drawn three kinds of arches with one opening of the compasses."

After the explanations given under No. 24 of the different forms of arches, it

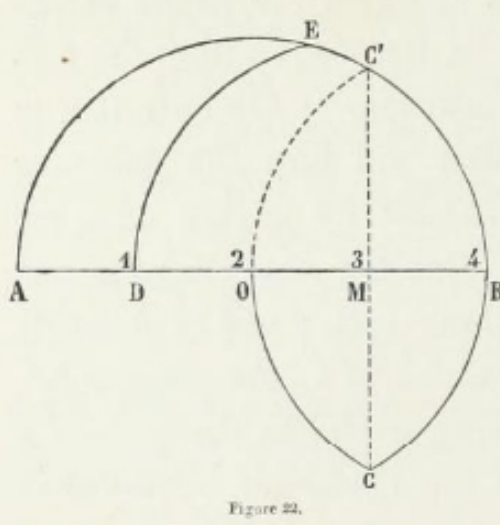
is only necessary to state that in this diagram a line $\mathrm{A} \mathrm{B}$ is drawn and divided into four equal parts in $\mathrm{D}, \mathrm{O}, \mathrm{M}, \mathrm{B}$. The opening of the compasses to be employed is the half of this line. Setting therefore the point of the instrument in the centre, $\mathrm{O}$, a semicircular arch, A E B, is first described. The point is next shifted to M, and the arc D E drawn, meeting the semicircle in $\mathrm{E}$. Thus we obtain the second arch, D E, B E, which is manifestly of the third point, as the centres from which it was struck are at

the points $\mathrm{O}, \mathrm{M}$, which divide the span D B into three. Lastly, the centre and so on (see the discussion in https://archive.org/details/facsimileofsketc00vill/ page/4/mode/2up at page 152. And Villard is showing how to make an equilateral arch too (no "vesica piscis"!).

Equilateral arch (architecture): "An arch described by two circular curves intersecting at the peak of the arch, each curve having a chord equal to the span" (McGraw-Hill Dictionary of Architecture and Construction. 2003). 

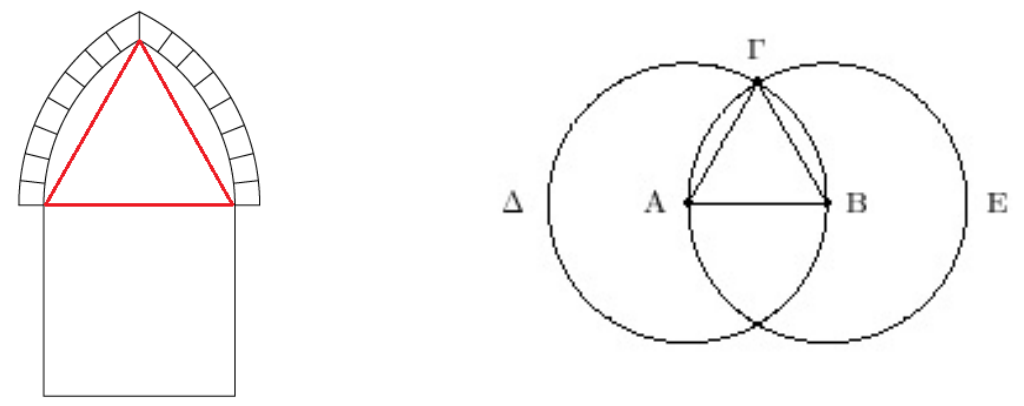

Equilateral arch on the left and the geometric lens with the equilateral triangle inside.
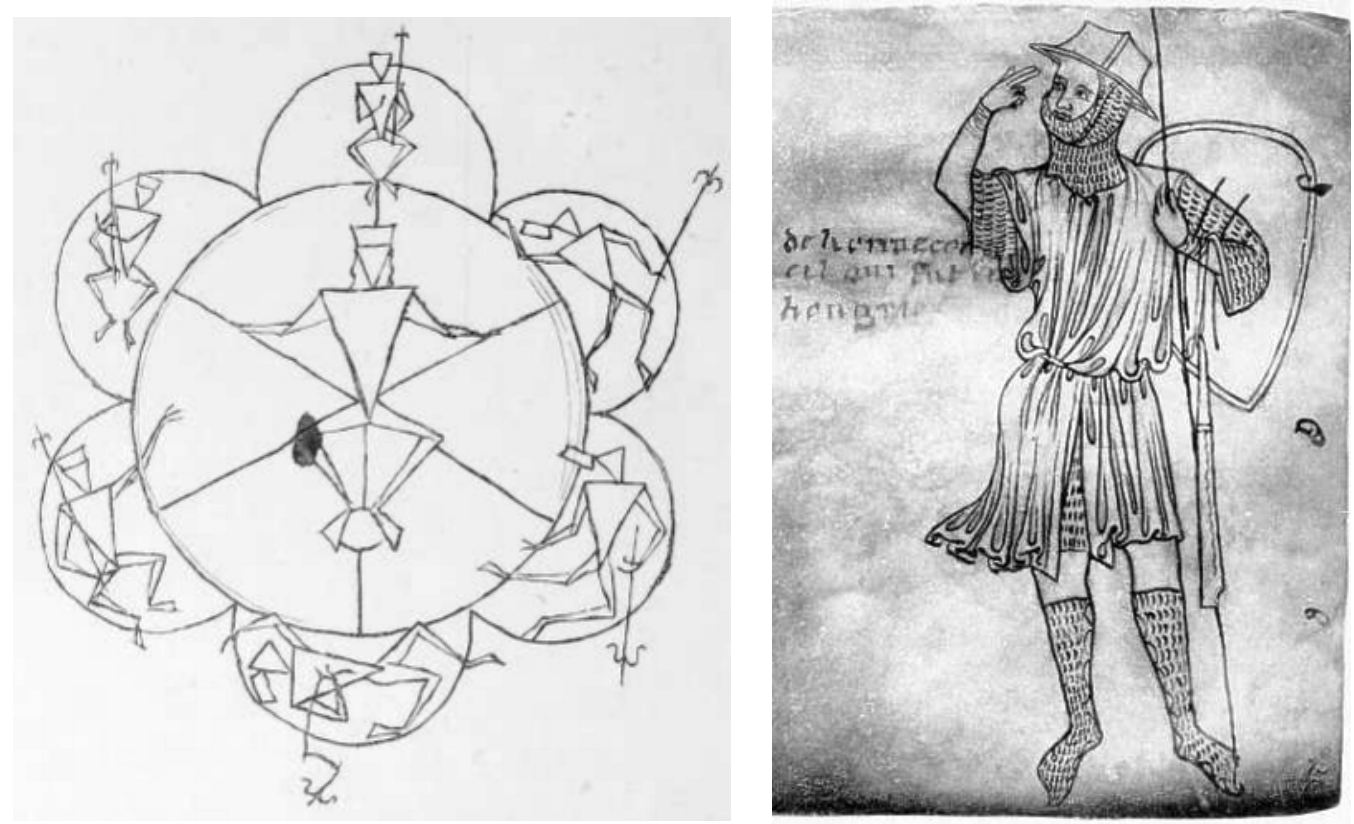

The Wheel of Fortune and a self-portrait (?) from the Notebook of Villard de Honnecourt (Courtesy GDK for Wikipedia)

\section{Notes and Queries}

On January 1884, the Oxford University Press published in its Notes and Queries a question and some answers. As we will see, it is evidenced the origin of the term from Albert Dürer. We will find also the observation by Didron. 
auertes.

We must request correspondents desiring information on family matters of only private interest, to affix their names and addresses to their queries, in order that the answers may be addressed to them direct.

" "Vesica PIScis,"-In the curious and interesting work of your correspondent Mr. Edmund Waterton, entitled Pietas Mariana Britannica, Lond., 1879, the object of which is to preserve every trace of the veneration of the Virgin Mary in this country existing in former days, the following quotation is made:- "In the centre boss over the entrance into the choir from the nave and transept in York Minster, our Lady is represented in a vesica piscis, which is borne by four angels, but she is not crowned (Browne's Bist. of the Min. Church of St. Peter, York, Lond., 1847)." Mr. Waterton remarks on this passage that he has often heard this figure (a drawing of which he gives) spoken of as intended to represent the Immaculate Conception, but thinks that from the absence of the requisite symbols it can only be meant for the Assumption (see part i. p. 238). As one very ignorant of such matters I would gladly be in. formed as to the precise meaning of the term vesica piscis, which I understand to refer to the surrounding ornamentation of the figure. I am, of course, aware of the origin and use of the sacred symbol IX $\Theta Y \Sigma$; also that the early Christians were wont to style themselves $P$ isciculi, fishes: "Nos pisciculi secundem $\iota x \theta v v$ nostrum Jesum Christum in aqua nascimur" (Tertullian).

I have consulted such works as Dr. Daniel Rock's Hierurgia and The Church of Our Fathers without finding any explanation of the phrase. Therefore I ask the assistance of any of your readers who are acquainted with the history of ecclesiastical symbolism. I think every one who is familiar with Oriental, that is to say Hindoo, religious ornament, and will take the trouble to compare with it the decoration in which the figure in question is set, must be struck with the curious similarity in style.

Alex. Fergusson, Lieut.-Col.

Lennox Street, Edinburgh.

\section{"VESICA PISCIS."}

(6 $6^{\text {th }} \mathrm{S}, \mathrm{ix} .327$.)

Didron (Bohn's edit., p. 108) objects to the term vesica piscis "as so gross that it should be expunged from every refined system of terminology." He proceeds to say that "it was invented and employed, even to abuse, by English antiquaries." The first assertion is foolish, and the second untrue. In fact, that a man of Didron's merit should commit himself to eitber statenient is a subject of marvel. In Parker's Glossary of Architecture it is said that Albert Dürer first applied the term vesica piscis, or fish-bladider, to the figure of the almond or aureole, which is an oval formed by the cutting or intersection of two equal circles, and that it is commonly employed to enclose each of the three persons of the Trinity and the Blessed Virgin. It is said to be symbolical of the word ${ }^{\prime} \chi \theta v s$, and so of the Saviour, with its cabalistic meaning, Jesus Christ, God's son, Saviour. The very enployment of the symbol disproves this. The Rev. T. Kerrick has tried to show that in this figure might be traced the principle of proportion employed by the medirval architects. This is another theory dreamed only by a man of leisure.

Col. Frrgussos hits upon the right idea in tracing the vesica piscis to the Hindoo sacred ornanjent. Hook, as quoted by Staunton in his
Ecclesiastical Dictionary, says that the vesica piscis has no reference, except in name, to a fish, but represents the almond, the symbol of virginity and self-production. Everything that is said about symbols is valueless unless you can get at the central idea, for otherwise you keep travelling in a circle, one idea running into another in perpetuity. It seems quite clear that the symbol of virginity cannot be the symbol of self-production, but only of potential generation, and that is undoubtedly what the vesica piscis means. The nimbus is found in the catacombs about the fourth century, and the Chevalier Rossi, in his learned work, Imagines selecte Deipure Virginis. 1862, attributes it to the epoch of Constantine; whilst the Abbé Auber, in his Symbolisme Religieux, iv. 85, writes: "Plus tard on inventa une distinction entre les Saints, dont nous savons le nimbe spécial, et Dieu la Vierge-Mère, à qui furent réservés ou le nimbe crucifére, nommé encore croisé, ou la gloire ou auréole."

Now, this settles the question for those who, unlike the Abbé, can see and have no theory to support. "Le nimbe crucifere" is the one productive agent; "la gloire ou auréole," the almond, and "vesica piscis" constitutes the other. Deity and nature are the two forces represented.
C. A. WARD. 
These words are defined in Pugin's Glossary of Ecclesiastical Ornament, p. 239, ed. 1846, as-

"A symbolical figure consisting of two intersecting aezments of circles, introduced as an emblem of our Lord. It is found from the fourth century downward. All senls of colleges, nbbeys, and other religious com. munities, as well as of ecciesiastical persons were made invariably of this shape."

In Durandus on Symbolism, by Neale and Webb (Leeds, 1843), 8vo. p. Ixxxii, another explanation is given :-

"The fish is the emblem of the Christisn as being born again of water. The mvstical verica piscis, of this form (), wherein the Divinity, snd (more rarely) the Blesed Virgin are represented, has no reference, except in its name, to a fish; but represents the almond, the symbol of virginity and self-production."

Lee, in his Glossary of Liturgical and Ecclesiastical Terms (London, 1877), has :-

"Vesica piscis (Latin, literally "the bladder of a fish"), a name applied by certain mediaval writers to $n$ pointed oval figure, formed by two equal circles, cutting each other in their centres, which is a common form given to the aureole or glory by which the representations of the Three Persons of the Blessed Trinity, and of our Blessed Lady, are surrounded in the paintings, sculp. tures, and carvings of the Middle Ages. Some see in this a reference to the IXOY $\boldsymbol{\Sigma}$. Rcclesiastical reals were mado in this form in the olden times in England-a form not lost even now."
Pugin, in the above extract, traces it back to the fourth century, but ventures on no opinion as to its origin. It may have been adopted from Hindoo religious ornamertation, as suggested by Cor. Fergusson, with some reference to expressions in John iii. This would require careful investigation, if, indeed, there are extant evidences by which the connexion could be established.

W. E. BUCKLet.

Some very curious details of the Eastern origin of this and other religious symbols will be found in Inman's Ancient Faiths embodied in Ancient Names, 2 vols. 8vo., 1872-73, and in the same author's smaller work, Ancient Faiths and Modern, 8vo., 1876 (New York), and other similar works quoted in these volumes, which need not be more fully described.

Estr.

[Mr. E. H. Mansnall supplies a definition from Pairholt's Dictionary of Art referg to Smith and Cheet. hnm's Dictionary of Christian Antiruities, s, v. "Fisb, and says, "It is an admitted rulo that medals for ecclesiastical service should be oval in shape, while those of a secular character are ordinarily round." MR. F. C. BIRKBRCK TERRY furnishes extracts from the Glossary of Terms and phraxes of the Rev, H. Percy Smith and Dr. Brewer's Dictionary of Phrase and Fable. Mr. EDMESD WATERTON and other correspondents are thanked for information concurring with what is found in one or other of the above communications.]

It is written "Vesica piscis ... a name applied by certain medieval writers to a pointed oval figure, ...". It is not rue, the name was invented by Dürer and translate into Latin by Kerrich.

\section{In Walcott's Sacred Archaology, under the word aureole, will be seen :- \\ "The aureole, which is never found in the catacombs. is usually an oval or elliptic in shape, and often filted with stars and figures of ancels. Its origin has been traced to the inagines clypeata (images within buckler*) of the Romans, in which a bust stands out from as shield. shaped round or orb. This was imitated by the Chris- tian arcbitects in early times, who placed a bust of the Saviour in a round blind window in the west front of a church. The vulgar name invented by Albert Dürer, and now exploded, for this form, when resembling the intersections of two circles, was vesica piscis."}

\section{A. HARRISON.}


"The vulgar name invented by Albert Dürer, and now exploded, for this form, when resembling the intersections of two circles, was vesica piscis".

\section{The symbol with the name}

From the Sketches of the History of Christian Art, Volume 1, by Alexander Crawford Lindsay, Earl of Crawford, Editor John Murray, Albemarle Street., 1847.

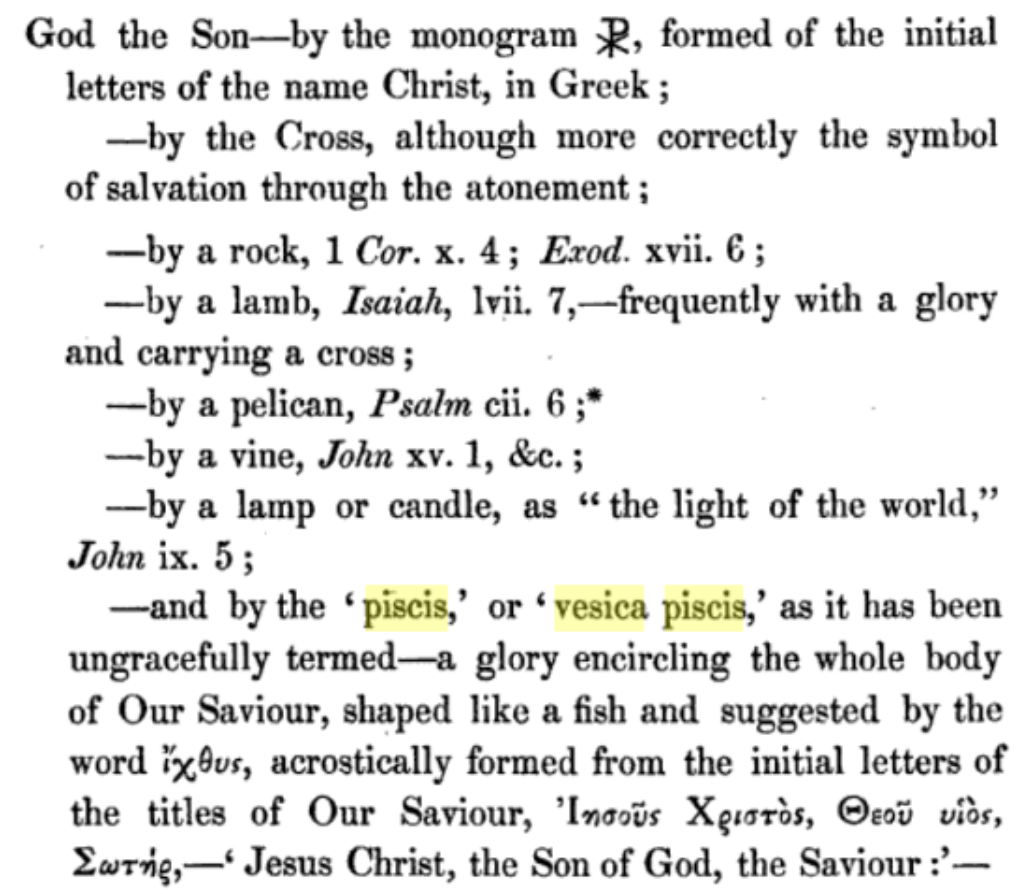

And even more we can find in The symbol of glory, shewing the object and end of freemasonry, by George Oliver, Jan 1850, R. Spencer editor. In this book, it is mentioned Lindsay's book.

And in The Discrepancies of Freemasonry, Examined During a Week's Gossip with the Late Celebrated Brother Gilkes and Other Eminent Masons : on Sundry Obscure and Difficult Passages in the Ordinary Lodge Lectures ...by George Oliver again, we can find, among the principal subjects of inquiry, a question: "You frequently allude to the "Vesica Piscis" in your publications - will you favour me with your opinion on its origin, use, and application to Freemasonry?".

"I allude, " said the Student, "to the Masonic application of the Vesica Piscis, which, 
we are told, is a universal exponent of architecture or Masonry, and the original source and fountain from which its signs and symbols are derived." ... "It may be unnecessary to observe," I remarked, "that the Vesica Piscis contains the imperfect outline of a FISH; and was so called from the" corresponding Greek word which is an acrostic of the Redeemer. And also, "whence it became an emblem of Christ, although it had been used geometrically long before His personal advent into the world. It appertained to the Platonic system, and constituted the sign of recognition amongst the Epopts, by the open hands united with the ends of the fingers, and wrists touching each other. Vesica Piscis often occurs in the Egyptian temples, and particularly about the throne of Osiris, in reference to the divine triads; and geometrically represents the birth of Light, Horns, or the Sun, from the wedding of Osiris and Isis."
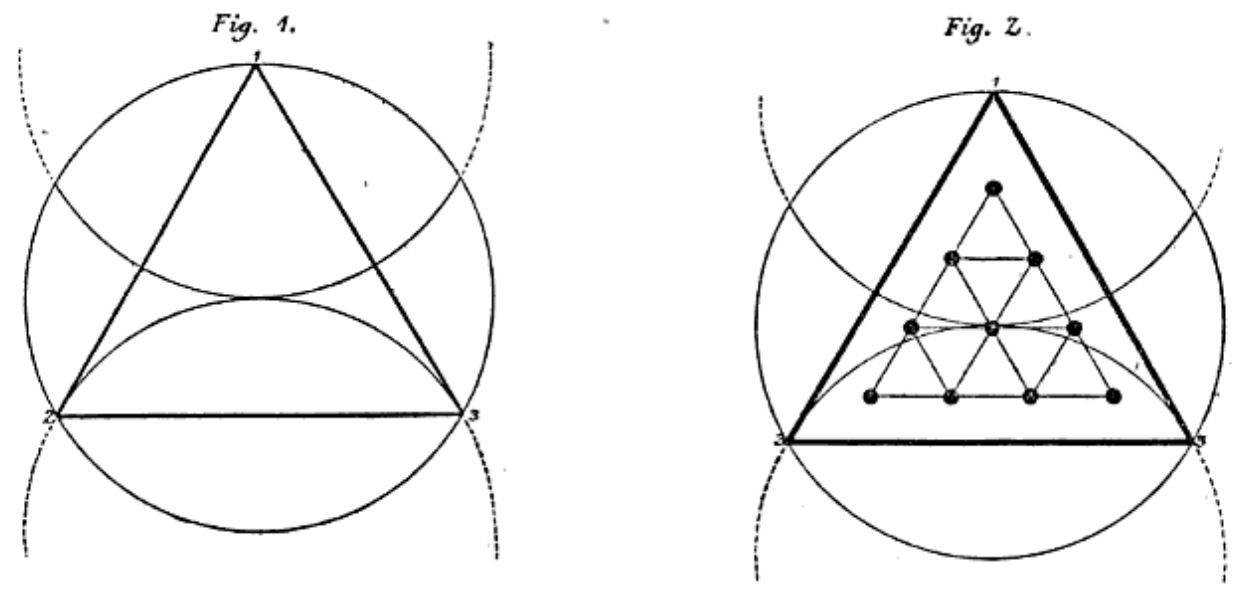

"But the question is, " the Surgeon asked, somewhat impatiently, " how do you apply it Masonically? ". "We apply it thus .... ". Admitted the "correctness", the book continues telling "The Vesica Piscis constitutes the origin and foundation of all these figures, and enters into the composition of almost every Masonic symbol. For instance, the number three refers to the Trinity in Unity, which is represented by a figure that Hemming and Shadbolt have denominated the Pythagorean Triangle, and illustrated thus (fig. 2). This emblem powerfully elucidates the mystic relation between numerical and geometrical symbols. It is composed of ten points so arranged as to form one great equilateral triangle, and at the same time to divide it into nine similar triangles of smaller dimensions. The first of these is called a Monad, and represents unity, answering to the geometrical point. The next two points are called Duad, answering to the geometrical line, which consists of length without breadth, and is bounded by two extreme points ....". 
We started our discussion on the symbol from Pythagoreans, but are we sure that it was the original Pythagorean point of view? In any case, the term "vesica piscis" is a Kerrich's contrivance. The link of Jesus to a fish, through the "vesica piscis", is a consequence of this contrivance.

\section{Google books from 1500 to 1600 and the mandorla of Giorgio Vasari}

We have seen that the term vesica piscis is a translation into Latin of the German "fischblosen". However, let us searching for "vesica piscis" among the Google Books from 1500 to 1600 . We find only books on animals and medicine. But, if we search for "mandorla" we find some books on geometry. But in geometry, the "mandorla" is a rhombus, as we can see from the Libro d'Architettura, by Sebastiano Serlio, appresso Francesco Senese [et] Zuane Krugher, 1566.

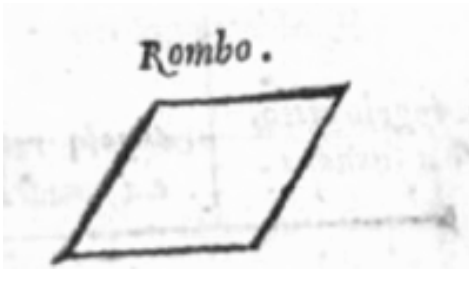

Rombo farà di quattro linee dingual lunghezza, dellequali fi potria far un quadrato perfetto: ma in quefta forma fard dise angoli acuti, es due ottufites quefla figura prende il nome da un pefce cbe fi dice Rombo, of ancora fi puo dire mandorla per bauer forma di mandorla.

And our mandorla is the figure "curvilinea biangola", with curvilinear angles as seen before.
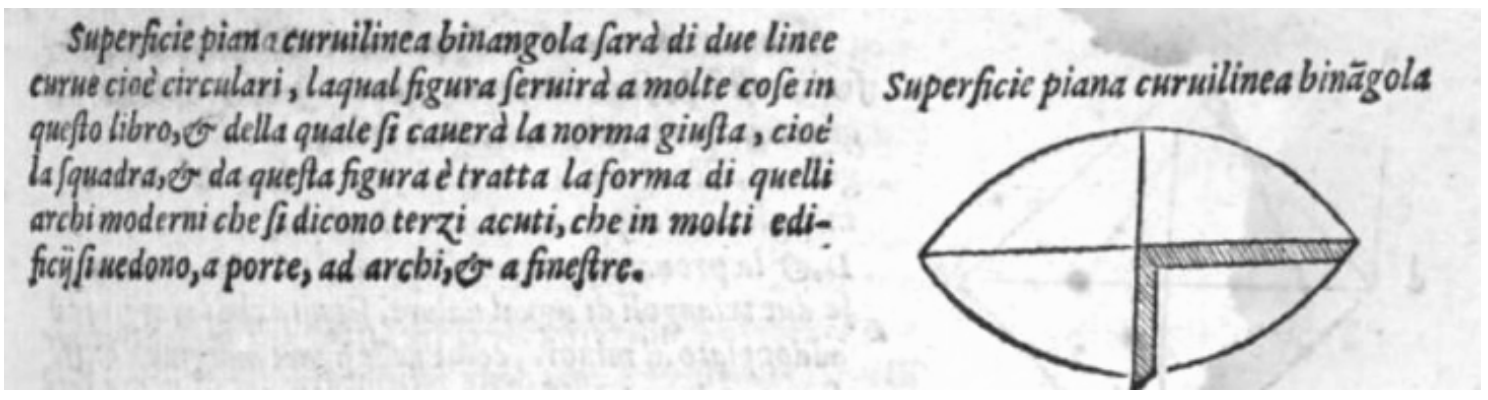

In his book on architecture, "Tutte l'opere d'architettura", Sebastiano Serlio, 1600, we find again the rhombus named "mandorla".

In the "Descrizione dell'apparato e degli intermedi fatti per la commedia rappresentata in Firenze nelle nozze de Seren. D. Ferdinando Medici, e Madame Cristina di Loreno 
Gran Duchi di Toscana", written by Bastiano de Rossi, 1589, we find "mandorla", to describe the light around artistic representations of the planets.

In "Due trattati uno intorno alle otto principali arti dell'oreficeria, l'altro in materia dell'arte della scultura, dove si veggono infiniti segreti nel lavorar le figure di marmo, [et] nel gettarle di Bronzo", by Benvenuto Cellini, editore Valente Panizzi, [et] Marco Peri, 1568, we find the "Mandorla del Suggello", the "mandorla" of the seal.

However we find also the Mandorla in the masterpiece of Giorgio Vasari, his book on the lives of painters and sculptors. Vasari (1511 - 1574) was an Italian painter, architect, writer, and historian, best known for his book entitled "Lives of the Most Excellent Painters, Sculptors, and Architects", which is considered the ideological foundation of art-historical writing. He was also the first to use the term "Renaissance" in print. And among the Google Books we find his Delle vite de' piu eccellenti pittori, scultori et architettori, apresso i Giunti, 1568. In it, we can read the description of the Porta della Mandorla of Florence cathedral. The name of the door is coming from its decoration showing the Madonna inside a Mandorla. Vasari made a mistake: he attributed this masterpiece to Jacopo della Quercia.

The Porta della Mandorla is considered the most beautiful of the four side doors of the cathedral. The name, as previously told, comes from the bas-relief above the door which has an image of the Madonna, the Virgin, within the elongated shape of an almond. In the bas-relief we can see angels and the Madonna being transported up to the heavens. The artist was Nanni di Banco and this masterpiece goes back to the early 1400 's.

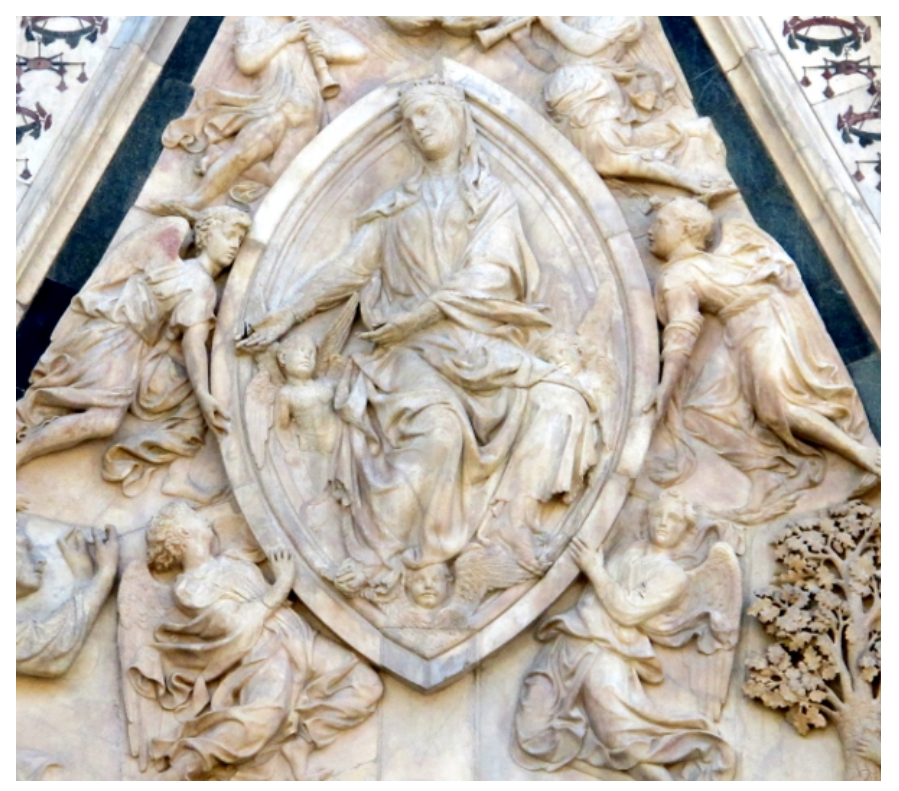


Another test that we can do is that of using Google Ngram Viewer and search for "vesica piscis". As previously told, it is a term coined by Kerrich. The first peak displayed by the curve at year 1801 is produced by the wrong automatic reading of the date of the book "The Ecclesiologist, Volume 7", Cambridge Camden Society, 1850 .

\section{Google Books Ngram Viewer}

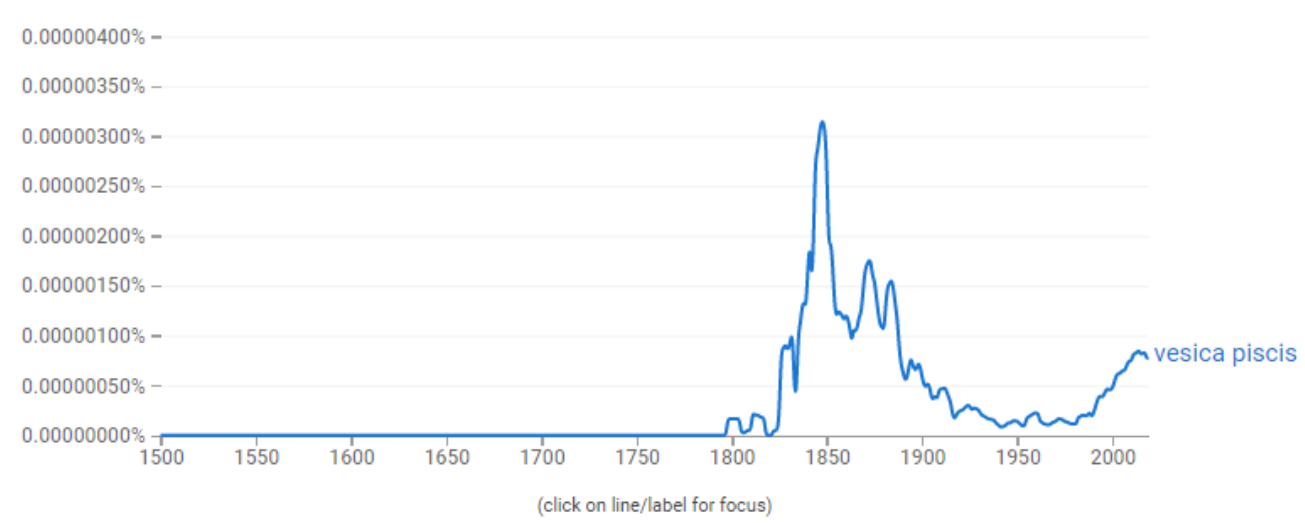

Actually, it seems that it would be better to use the term "mandorla" for what is concerning arts and symbols, and architecture too (see the "Arco della Mandorla" in Perugia), and "vesica piscis" for geometry. In any case, we have found that it was in the early nineteenth century that the German "fischblosen" became the Latin "vesica piscis".

\section{Conclusion}

Here we have proposed a discussion about the names of a symbol ("vesica piscis" or "mandorla"). We have found that the name "mandorla" was used long before the term "vesica piscis", which is the Latin translation of the German "fischblosen" that we find in the book by Albert Dürer on geometry. The name invented by Albert Dürer was not used by the painter for a sacred form. However, after the middle of the nineteenth century the term "vesica piscis" exploded in literature. Its use was 
criticized and, at the same time, it was stressed that the proper term for the symbol is "mandorla". Nonetheless, the "vesica piscis" continues to be largely used in the sacred geometry, which ascribes symbolic and sacred meanings to certain geometric shapes and proportions. We have also discussed that, recently, the mandorla was related to the Pythagorean philosophy and secret symbols involving the core of the apple.

Actually, our investigation about the terms used for a geometric symbol reached the core of the matter, or, let us tell the "core of the apple", in a Pythagorean-like approach, by showing how a German "fischblosen" evolved into a sacred symbol, thanks to a translation into Latin.

\section{References}

[1] Sparavigna, Amelia Carolina. (2020, November 25). The Vesica Piscis (Mandorla) and the Geometry of the Square Roots. Zenodo. http://doi.org/10.5281/zenodo.4290813

[2] Sparavigna, Amelia Carolina, Light and Shadows in Bernini's Oval of Saint Peter's Square (November 8, 2015). PHILICA Article number 540, Available at SSRN: https://ssrn.com/abstract=2742281 or http://doi.org/10.5281/zenodo.3908973

[3] Sparavigna, Amelia Carolina and Baldi, Mauro Maria, Overlapping Circles Grid Drawn with Compass and Straightedge on an Egyptian Artifact of 14th Century BC (March 18, 2016). Available at SSRN: https://ssrn.com/abstract=2750125 or http://dx.doi.org/10.2139/ssrn.2750125

[4] Sparavigna, Amelia Carolina and Baldi, Mauro Maria, Flower of Life, Six-Fold Symmetry and Honeycomb Packing of Circles in the Mycenaean Geometry (March 29, 2016). Available at SSRN: https://ssrn.com/abstract $=2756099$ or http://dx.doi.org/10.2139/ssrn.2756099

[5] Kate Hobgood. Pythagoras and the Mystery of Numbers. Available at http://128.192.17.191/EMAT6680Fa06/Hobgood/Pythagoras.html archived https://archive.vn/TJeeN

[6] Graham Hancock (2010). The Mars Mystery: The Secret Connection Between Earth and the Red Planet. Crown, Aug 11, 2010.

[7] Amelia Carolina Sparavigna, Mauro Maria Baldi. A Study of the Regular Pentagon with a Classic Geometric Approach. 2016. 〈hal-01295771v2〉

[8] Emerson DeAnna (1996). Mars/Earth Enigma: A Sacred Message to Mankind. Galde Press, Inc., 1996 
[9] Brenda Sullivan (2001). Africa Through the Mists of Time, Covos Day, 2001 [10] Derek Thomas (2007). Architecture and the Urban Environment. A Vision for the New Age. Routledge, Jun 1, 2007

[11] Rostislava Todorova (2011). THE MIGRATING SYMBOL: VESICA PISCIS FROM THE PYTHAGOREANS TO THE CHRISTIANITY. March 2011. Conference: 1th International Conference HARMONY OF NATURE AND SPIRITUALITY IN STONE At Kragujevac, Serbia.

[12] Rostislava Todorova (2016). The Aureole and the Mandorla: Aspects of the Symbol of the Sacral from Ancient Cultures to Christianity. January 2016. In book: STUDIA ACADEMICA ŠUMENENSIA, Shumen University Press. Editors: Ivo Topalilov, Biser Georgiev.

[13] Hagstrom, A. A. (1998). The Symbol of the Mandorla in Christian Art: Recovery of a Feminine Archetype', ARTS 10, 2, 25-29.

[14] Pearson, A. E. (2002) Revealing and Concealing: The Persistence of Vaginal Iconography in Medieval Imagery: the Mandorla, the 'Vesica Piscis', the Rose, Sheela-na-gigs and the Double-Tile Mermaid, Unpublished PhD thesis in Religious Studies, University of Ottawa.

[15] Didron. Adolphe Napoleon. 1965. Christian lconography: the History of Christian Art in the Middte Ages. First volume. New York: Frederick Ungar Publishing Co.

[16] Gordon Hughes (2012). The Polygons of Albrecht Durer -1525. Arxiv: History and Overview (math.HO). arXiv:1205.0080

[17] T. Kerrich. Observations on the Use of the Mysterious Figure, called Vesica Piscis, in the Architecture of the Middle Ages, and in Gothic Architecture.

Archaeologia, Volume 1918-21 , pp. 353-368. XXXVII. by T. Kerrich, M.A. F.S.A. Principal Librarian to the University of Cambridge. DOI:

$10.1017 / \mathrm{S} 0261340900023067$ 